\title{
THE UNSETTLED BUSINESS: SHOULD ANTIDUMPING LAWS BE REPLACED BY COMPETITION (ANTITRUST) LAW UNDER FREE TRADE?
}

\section{CHRISTOPHER KENT ${ }^{*}$}

Some academics conclude that antidumping laws are no longer necessary in the era of the North American Free Trade Agreement and can be replaced by competition (antitrust) laws. However, the author argues that Canada and the United States have not achieved the degree of free trade necessary to eliminate the need for antidumping law.

The article begins by providing an in depth analysis of the operation of the North American Free Trade Agreement (NAFTA), the Free Trade Agreement (FTA) and the General Agreement of Tariffs and Trade (GATT) before examining the Canadian and American approaches to antidumping law. Then, using the writings and concepts of Jacob Viner, the author demonstrates that non-predatory. intermittent dumping may continue to occur under the NAFTA, thus necessitating the maintenance of antidumping law in a modified form.

The author also submits that existing bodies of competition law could not fill the void created by $a$ repeal of the antidumping laws, primarily because of the fundamental differences which exist between Canadian and American approaches to antitrust law. In order to do so, a significant amount of American material is also examined.
Certains spécialistes affirment que les lois antidumping ne sont plus nécessaires à l'ère de l'Accord de libre-échange nord-américain et qu'elles peuvent être remplacées par les lois sur la concurrence (antitrust). Mais l'auteur soutient que le Canada et les Etats-Unis n'ont pas atteint le degré de libre-échange qui justifierait une telle initiative.

Avant d'examiner l'approche du Canada et des Etats-Unis envers les lois antidumping, l'auteur procède à une analyse approfondie de l'application de l'Accord de libre-échange nord-américain (ALENA), de l'Accord de libre-échange entre le Canada et les États-Unis (ALE) et de l'Accord général sur les tarifs douaniers et le commerce (GATT). Il utilise ensuite les travaux de Jacob Viner pour démontrer que le dumping intermittent et la pratique de prix abusifs peuvent encore se produire dans le cadre de l'ALENA, ce qui justifie le maintien des lois antidumping sous une forme modifiée.

$L$ 'auteur soutient aussi que les lois actuelles sur la concurrence ne suffiraient pas à combler le vide laissé par l'abrogation des lois antidumping, compte tenu des différences fondamentales d'approche qui séparent les Canadiens et les Américains en matière de législation antitrust. $L$ 'auteur fonde son analyse sur une documentation américaine considérable.

\section{TABLE OF CONTENTS}

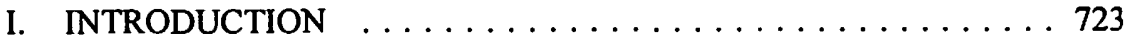

II. THE FTA, THE NAFTA AND THEIR

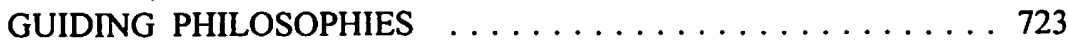

III. ANTIDUMPING LAW IN CANADA AND THE UNITED STATES $\ldots \ldots \ldots \ldots \ldots \ldots \ldots \ldots \ldots \ldots \ldots$

IV. DO WE NEED ANTIDUMPING REGULATION

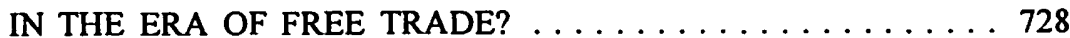

V. COMPETITION LAW UNDER FREE TRADE:

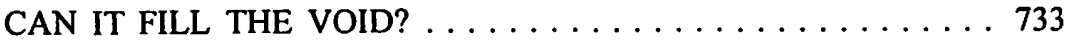

VI. CONCLUSION $\ldots \ldots \ldots \ldots \ldots \ldots \ldots \ldots \ldots \ldots \ldots \ldots \ldots \ldots$

McGill University, National Program. The author will be joining the firm of Flavell, Kubrick \& Lalonde in Ottawa as an associate in 1995. The opinions expressed in this article are those of the author only. 


\section{INTRODUCTION}

It is surprising that more reference is made to theory than to reality in a great deal of the contemporary discussion of the compatibility of antidumping law and free trade. The general trend of writers is to argue that only one form of transborder price discrimination, so-called "predatory" dumping, can be justifiably punished and that predatory dumping may be adequately regulated by competition (antitrust) provisions.' Based on this argument, it is concluded that there is no reason why current antidumping law could not be eliminated and replaced by existing bodies of competition law.

In an ideal international economy where barriers to the free flow of goods and services have been completely eliminated, such opinions are compelling. The purpose of this article is to demonstrate that Canada and the United States, in the era of the North American Free Trade Agreement (NAFTA), ${ }^{2}$ will not yet have reached the stage where no legitimate role for antidumping laws exists. As a matter of necessary background, the guiding philosophy of the Canada-U.S. Free Trade Agreement $(F T A)^{3}$ and the NAFTA will first be discussed. Next the substance of relevant provisions of the General Agreement on Tariffs and Trade 4 and of Canada's and the United States' antidumping laws will be summarized. Based on this background, the remainder of the article will be devoted to the discussion of two main issues:

1. Whether there is still a role that antidumping laws should fulfil, given the reality of "free trade" achieved by the FTA and now by the NAFTA; and

2. Whether such a role, if it exists, may be adequately fulfilled by existing Canadian and U.S. bodies of competition (antitrust) law.

\section{THE FTA, THE NAFTA AND THEIR GUIDING PHILOSOPHIES}

When the FTA came into force on January 1,1989, new principles of enhancing "the competitiveness of Canadian and United States firms in global markets", promoting "productivity, full employment, and a steady improvement of living standards in their respective countries," and reducing "government-created trade distortions while

See inter alia I.R. Feltham et al., "Competition (Antitrust) and Antidumping Laws in the Context of the Canada-United States Free Trade Agreement" (1991) 17 Can-U.S. L.J. 71; P. Warner, Round Two of the Canada-U.S. Free Trade Agreement: The Case for Replacing Antidumping with Antitrust (Toronto: Ontario Centre for International Business, 1990) at 43; T.M. Boddez \& M.J. Trebilcock, Unfinished Business: Reforming Trade Remedy Laws in North America (Winnipeg: Kromar Printing, 1993) at 185, 203-259; J.J. Barcelo, "Antidumping Laws as Barriers to Trade: The United States and the International Dumping Code" (1972) 57 Cornell L. Rev. 491. 32 I.L.M. 297 (1993) [hereinafter NAFTA]. Of course Mexico is a member of the NAFTA as well. However, this article focuses on NAFTA's two other member states: Canada and the United States. For the complete text of the NAFTA see North American FTA, available in Lexis, Trade Library Hottop file and Westlaw, International Law NAFTA Database.

322 December 1987, Can. T.S. 1989 No. 3, 27 I.L.M., art. 1806; Part A, Schedule to the CanadaUnited States Free Trade Agreement Implementation Act, S.C. 1988, c. 65 [hereinafter FTA].

455 U.N.T.S. 187. Current amended version appears at (1965) vol. IV B.I.S.D. 1 [hereinafter GATT]. 
preserving the parties' flexibility to safeguard the public welfare," 5 among others, were supposed to become the guidelines of the trading relationship between Canada and the United States. These objectives were to be achieved through several means, including:

(a) eliminating barriers to trade in goods and services between the territories of the parties;

(b) facilitating conditions of fair competition within the free trade area;

(c) liberalizing significantly conditions for investment within this free-trade area; and

(d) establishing effective procedures for the joint administration of this Agreement and the resolution of disputes... ${ }^{6}$

In other words, Canada and the United States had taken the first steps toward the creation of a free trade area for goods and services, where economic efficiency and not protectionism would be the guiding principle. The NAFTA reiterates the substance of this guiding philosophy.

The NAFTA and the FTA must be lauded for replacing traditional judicial review by domestic courts of final antidumping and countervailing duty determinations with a supranational panel review process. ${ }^{8}$ Under both agreements, member states, as well as individual parties to domestic antidumping or countervailing duty procedures, may request the establishment of a Chapter 19 panel. ${ }^{9}$ These panels are empowered to send decisions back to domestic authorities for action not inconsistent with the panel's decision. ${ }^{10}$ The standard of review and legal principles applied by Chapter 19 panels are those of the importing country" and panel decisions are binding on parties. ${ }^{12}$

It is generally agreed that subjecting Canada and the United States to binding binational panel review has significantly reduced the protectionist use of trade law remedies. ${ }^{13}$ However, neither the FTA nor the NAFTA goes so far as to replace

FTA, supra note 3, preamble.

Ibid. art. 102.

See NAFTA, supra note 2, preamble, art. 102.

Ibid. art. 1904, FTA, supra note 3 art. 1904.

NAFTA, ibid. art. 1904(5); FTA, ibid. art. 1904(5).

NAFTA, ibid. art. 1904(8); FTA, ibid. art. 1904(8).

NAFTA, ibid. art. 1904(3); FTA, ibid. art. 1904 (3).

NAFTA, supra note 2, art. 1904(9); FTA, ibid. art. 1904(9). For more detailed discussion of this Chapter 19 dispute resolution mechanism, see W.C. Graham, "Dispute Resolution in the CanadaU.S. Free Trade Agreement: One Element of a Complex Relationship" (1992) 37 McGill L.J. 544 and G.W. Winham, "Dispute Resolution in NAFTA and the FTA" The NAFTA Network (Vancouver: The Fraser Institute, 1993).

13 See for example G.C. Hufbauer \& J.J. Schott, North American Free Trade: Issues and Recommendations (Washington: Institute for International Economics, 1992) at 38:

Panels have not acted as rubber stamps for national regulators; instead, some national actions have been overturned. Moreover, the decision by an extraordinary challenge committee to uphold the panel findings in the most contentious case to date - a dispute involving Canadian pork subsidies seems to have bolstered the credibility of the FTA process. 
existing antidumping and countervailing duty law with a uniform framework that is no longer capable of protectionist manipulation. ${ }^{14}$

In anticipation of more effectively addressing the issue of abuse of trade remedies, the FTA left the door open for development of a "substitute system of rule for dealing with unfair transborder pricing practices and government subsidization." goes even further with the addition of Chapter Fifteen, entitled "Competition Policy, Monopolies and State Enterprises". Under art. 1504 the Free Trade Commission will have the duty to create a Working Group on Trade and Competition:

...comprising representatives of each party, to report, and to make recommendations on further work as appropriate, to the Commission within five years of the date of entry into force of this Agreement on relevant issues concerning the laws and policies and trade relationship between competition in the free trade area. ${ }^{16}$

Almost certain to be discussed by the NAFTA Working Group will be the theoretical and practical feasibility of replacing existing antidumping laws in force in Canada, the United States and Mexico with a uniform or harmonized body of competition law. This essay will examine such feasibility in the context of Canada and the United States.

\section{ANTIDUMPING LAW IN CANADA AND THE UNITED STATES}

Historically, antidumping measures in Canada and the United States have been governed by a set of relatively weak guidelines. Art. VI of the GATT, in combination with the GATT Antidumping Code, ${ }^{17}$ requires that three principal criteria must be satisfied in order for transborder price discrimination to be justifiably condemned by the imposition of an antidumping duty. In the first place, a "margin of dumping" must exist. A margin of dumping is defined to exist if the product is being introduced into an importing country at a price less than its "normal value", the latter defined to constitute one of three values: the home market price, or, in the absence of such a price, the highest third market price or the cost of production in the country of origin. Thus, mere discrimination between the price set in the importing country and that charged in the country of origin is sufficient to establish a "margin of dumping", provided due allowance is made for "differences in conditions and terms of sale, for differences in taxation, and for other differences affecting price comparability."

FTA, supra note 3, art. 1902. Indeed, NAFTA, supra note 2, art. 1902(1) reads:

Each Party reserves the right to apply its antidumping law and countervailing duty law to good imported from the territory of any other Party.

The specific areas where trade barriers and potential protectionist use of trade remedies remain are discussed in more detail at infra notes 53-59.

is FTA, ibid. art. 1906.

16 NAFTA, supra note 2, art. 1504. See J.L. Siqueiros, "NAFTA Institutional Arrangements and Dispute Settlement Procedures" (1993) 23 Calif. West Int'l L.J. 383.

$17 \quad$ The Agreement on the Implementation of art. VI of the GATT, (1979) B.I.S.D., 26th Supp. [hereinafter GATT Antidumping Code]. 
The second requirement for an permissible antidumping duty, enunciated in art. VI of the GATT, is that the dumping "causes or threatens to cause material injury to an established industry in the territory of a contracting party or materially retards the establishment of a domestic industry." ${ }^{\prime 9}$ Clearly, this threshold is not restrictive upon the contracting parties: the intent of the dumping firm need not be predatory (i.e. to reduce competition) and no analysis of the relation of the dumping price in relation to the actual cost of production is mandatory in order for a legitimate antidumping duty to be imposed.

The final requirement, established by the GATT Antidumping Code, is that the dumping must be the "principal cause" of the material injury. It is not clear from the GATT Antidumping Code how proximate the causation relationship must be in order for antidumping duties to be imposed, although the GATT Antidumping Code makes it clear that there may be other factors which at the same time are injuring the industry and that such injuries must not be attributed to the dumped imports. ${ }^{20}$

This logic of the GATT is reflected in Canadian antidumping legislation. In Canada, the Special Import Measures Act of $1984\left(\right.$ SIMA) ${ }^{21}$ provides a two-pronged procedure for an antidumping action: first, Revenue Canada (Customs and Excise) must determine whether dumping has occurred and whether, on the facts of the case, there exists a prima facie basis for the determination of injury. In the spirit of the GATT, a margin of dumping is calculated primarily as the difference between the import price and the "normal value", determined by the price of like goods in the domestic market ${ }^{22}$ or the domestic cost of the goods plus an allowance for profit. ${ }^{23}$

Next, it is the role of the Canadian International Trade Tribunal to determine if the dumping caused material injury or retardation to the production in Canada of like goods. ${ }^{24}$ No predatory intent requirement exists under the SIMA. Indeed, in the Cars (Hyundai) case, ${ }^{25}$ the Canadian International Trade Tribunal emphasized that had intense competition from other domestic competitors not broken the chain of causation, price suppression and margin erosion in one segment of G.M. and Ford's total market (smaller cars) would have been sufficient to justify the imposition of an antidumping duty.

GATT, ibid. art. VI(1). Art. 3(3) of the Gatt Antidumping Code provides an inexhaustive list of factors pertinent to the determination of injury. These factors include: actual and potential decline in output in the domestic industry affected, decline in sales, market share, profits, productivity, return on investments or utilization of capacity; factors affecting domestic prices; actual and potential effects on cash flow, inventories, employment, wages, growth, ability to raise capital or investments.

GATT Antidumping Code, supra note 17, art. 3(4).

Special Import Measures Act, R.S.C. 1985, c. S-15 [hereinafter SIMA].

SIMA, ibid. s. 17. See also SIMA, ibid. s. 24 where in accordance with GATT, art. VI, provision is made for additional costs incurred by the dumper.

While this description is a simplification of the methods used under the SIMA, it captures their essence.

SIMA, ibid. s. 42.

(1988) 16 C.E.R. 633. 
Interestingly, most U.S. academics agree that by requiring intent to injure or prevent the establishment of an industry in the United States in order for a duty to be imposed, the first piece of U.S. antidumping legislation, the Antidumping Act of $1916,{ }^{26}$ was in essence a form of antitrust law. ${ }^{27}$ It was largely in response to the lack of such a predatory intent requirement in corresponding Canadian antidumping law $^{28}$ that, in 1921, Congress removed the intent requirement. ${ }^{29}$ The logic of the 1921 Act was maintained in the Trade Agreements Act of $1979^{30}$ and the Omnibus Trade and Competitiveness $A \mathrm{At}^{31}$ of 1988 , under which, consistent with the GATT, intent to harm competition or create a monopoly are not of essence; rather one must establish that "by reason of unfair pricing, a U.S. industry is suffering, or is likely to suffer material injury." ${ }^{32}$

Even with such language, which is unequivocally aimed at conduct beyond mere predation, there have been judicial attempts to reconstrue these provisions to be more in accord with U.S. antitrust law. Susan Liebeler, the Vice Chairperson of the ITC, for example, wrote a concurring decision in the U.S. dumping case of Certain Red Raspberries from Canada. ${ }^{33}$ In that decision, Liebeler interpreted the Antidumping Act to require five substantive conditions for the imposition of an antidumping measure against an importer:

1. A dominant market position of the importer;

2. High dumping margins;

3. Homogeneity of the dumper's and competitors' products;

4. Declining prices in the affected market; and

5. Barriers to entry to other foreign producers. ${ }^{34}$

According to Gifford, ${ }^{35}$ Liebeler's fifth requirement, the existence of barriers to entry to other foreign producers, can only be understood in terms of predatory intent, as such barriers create the environment necessary for the importing firm to enjoy a monopoly position in the importing market as a result of dumping. However, any doubt concerning the scope of antidumping law in the United States has been soundly eliminated after the case of USX Corp. v. United States, ${ }^{36}$ where it was held that in

Act of Sept. 8, 1916, ch. 463, s. 801, 39 Stat. 798 (1916) (codified as amended at 15 U.S.C. s. 72 (1988)).

See inter alia Wood, "Unfair Trade Injury: A Competition-Based Approach", (1989) 41 Stan. L. Rev. 1153 at 1158 and Comment, "The Antidumping Act - Tariff or Antitust Law?" (1965) 74 Yale L.J. 707 at 714.

See An Act to Amend the Customs Tariff, 1897, 4 Edw. 7 c. 11, s. 19 (1904).

See Antidumping Act of 1921 , c. 14, s. 201, 42 Stat. 11 (1921) [hereinafter 1921 Act]. 93 Stat. 162 (1979) codified at 19 U.S.C. S. 1673 (1988) [hereinafter Antidumping Act]. 102 Stat. 1107.

Antidumping Act, supra note 30, Title VII.

USITC Pub. No. 1707, Inv. No. 731-YTA-196 (final) (June 1985).

lbid. at 16.

See D.J. Gifford, "Rethinking the Relationship between Antidumping and Antitrust Laws" (1991) 6 Am. U.J. Int'l L. \& Pol'y 277 at 303-4.

682 F. Supp. 60. (Ct. Int'l Trade 1988). 
addition to predatory pricing, the Antidumping Act "is directed against all dumping that produces an 'injury to [American] industry'." 37

\section{DO WE NEED ANTIDUMPING REGULATION IN THE ERA OF FREE TRADE?}

The argument for the revocation of antidumping regulation in an international market, where all barriers to the free flow of goods and services have been removed, is convincing in theory. Barcelo presents the example of firm that enjoys relative market power in its market of origin but experiences a higher price elasticity of demand in a foreign market, as compared to the home market. ${ }^{38}$ Under this scenario, behaviour that would allow for the most effective allocation of resources would in fact be for the firm to engage in non-predatory price discrimination: to charge a lower price in the importing market relative to the market of origin. In the words of Barcelo, the competitive benefits of such behaviour in the importing market are indisputable:

In this market more goods will be supplied at a lower price if dumping is allowed. The lower price will also more closely approximate the dumper's marginal cost, the ideal welfare point at which consumer satisfaction from the last unit sold just matches the cost of producing that unit. ${ }^{39}$

Feltham, in reference to a similar scenario, extends this logic and concludes that not only are antidumping laws harmful to domestic competition, but they run counter to some of the stated objectives of the FTA as well:

The risk of maintaining antidumping rules under the $F T A$ is that this would defeat vigorous transborder price competition that is not predatory and would therefore inhibit vigorous competition among Canadian and U.S. players. Moreover the risk of having to face antidumping actions could inhibit rationalization by unilateral enterprises operating in the two countries. This would be counter to the goal of improving global competitiveness of North America's industrial base. ${ }^{40}$

Tied closely to the goal of promoting "vigorous competition among Canadian and U.S. players" is the need for a so-called "level playing field" for these firms. With this in mind, the framers of the FTA adopted the GATT principle of national treatment as the fundamental standard of the new Canada U.S. trade relationship. In the words of Feltham, "once the good or service passes the border hurdle of, say, payment of a tariff, then the good or service can no longer be subject to any form of discrimination." ${ }^{41}$ It is noteworthy that each country has to "reserve" its right to apply domestic antidumping law, since otherwise these provisions would be subject to challenge as being contrary to the substantive national treatment standard embodied in art. 501 of the FTA and art. 301 of the NAFTA. ${ }^{42}$ Antidumping laws, by being targeted solely toward importing

Gifford, supra note 35 at 304, quoting USX Corp. v. United States, ibid. at 66.

See Barcelo, supra note 1 at 507.

Ibid.

See Feltham et al., supra note 1 at 79-80.

Ibid. at 159.

See FTA, supra note 3, art. 1902 and NAFTA, supra note 2, art. 1902. FTA, ibid. art. 501 and $N A F T A, i b i d$ art. 301 explicitly give primacy to the GATT national treatment standard. 
firms and by denying these firms the equal opportunity to invoke them against domestic producers, may be argued to be discriminatory and would hence be contrary to the standard of national treatment. ${ }^{43}$

The procedural advantages that Canadian and U.S. antidumping laws bestow upon domestic firms, with provisional remedies and lengthy processes ${ }^{44}$ may also be shown to be discriminatory and contrary to the principle of national treatment. Fried characterizes this as a "litigation bias" in favour of domestic firms that can be used as "...an ordinary tool of business strategy, e.g. to 'buy time' against a competitor. ${ }^{45}$

While the preceding arguments are intuitively appealing, it is the opinion of this author that they ignore at least one important concern that antidumping laws address - a concern that will not be eliminated under North American free trade in its current form. In order to illustrate this concern one must be familiar with the influential writings of Jacob Viner who did not focus on the distinction between dumping as predatory or non-predatory, but rather as "persistent" versus "intermittent" and "sporadic". 46

According to Viner, persistent dumping occurs where a firm sets a price in the importing market that is perpetually lower than in its home market. The desirability of such activity for the importing market is clear: the market benefits from a dependable, low cost source of supply. ${ }^{47}$ At the other end of the spectrum, sporadic dumping is a brief phenomenon which occurs in response to unexpected market fluctuations; it therefore is not a danger to efficient producers in the importing country.

Viner submits that it is intermittent dumping, whether predatory or non-predatory, that is dangerous to the importing nation because it produces a lose-lose situation for consumers and producers. Commentators generally illustrate the phenomenon of nonpredatory intermittent dumping with the scenario of an importer who, in order to maintain its high domestic monopoly or oligopoly prices, dumps in the importing market in times of seasonal fluctuation. ${ }^{48}$ Consider, however, another scenario (one which, incidentally, could be common under the NAFTA): Firm A is a legally protected monopolist or oligopolist in its domestic market, (country X), or has obtained a competitive advantage in country $X$ through the unilateral imposition of a countervailing duty by the government of country X. Firm A becomes interested in

Importing firms may arguably invoke the SIMA against another importer if they can show that they intend to establish production facilities in Canada and such activity is being retarded by the activity of the other importer. The requirement of domestic production or intended domestic production in Canada is onerous, however, particularly for those firms which can efficiently distribute products to Canada from existing foreign production sites; in this sense the SIMA places importing firms in a comparatively disadvantaged position in relation to their Canadian counterparts. For the United States see 19 U.S.C. ss. 1673(a)-(d) and for Canada see SIMA, supra note 21, ss. 35(1), 38(1), $41(1)$. See J.T. Fried, "The Challenge of the F.T.A. - Chapter 19" (1991) 17 Can.-U.S. L.J. 11 at 13. J. Viner, Dumping: A Problem in International Trade (Chicago: University of Chicago Press, 1923).

47 See Gifford, supra note 35 at 305.

4 Ibid. at 310-12. 
expanding into the deregulated market of country $Y$ due to the lowering of customs tariffs in country $Y$ and decides to pursue a strategy of non-predatory price discrimination, whereby it uses its artificially inflated domestic profits to temporarily subsidize a lower price in country $\mathrm{Y}$ in order to obtain a market share sufficient to establish a competitive distribution network. Firm A's intention is to raise the price of its product to market levels once a sustainable market share is achieved (i.e. its intent is therefore not predatory); however, like any business, Firm A may choose at any time to discontinue distribution in country $\mathrm{Y}$, based on periodic evaluations of its strategy.

From the perspective of producers in country $Y$ who compete with Firm $A$, the unfairness of the strategy lies in the existence of an "uneven playing field" in country $X$. Under such a situation, producers in the importing market could find themselves in the unfair situation of being forced to temporarily meet the below average total cost prices of the dumping firm for sustained periods of time without the corresponding benefit of access on equal terms to the more lucrative home market of the dumper. ${ }^{49}$

Flowing closely from such a situation is the resulting phenomenon of uncertainty. Otherwise efficient firms in the importing market could find themselves needing to add an investment "risk premium" in order to offset uncertainty in their profitability due to fluctuations in the competitive environment caused by such dumpers. The result will be distortion of the importing country's market - particularly in capital intensive industries - as intermittent dumping will "divert commerce and industry' out of 'their natural channels,' thereby conflicting with the objectives of free trade." ${ }^{50}$ At worst, competing firms could be driven out of the market by such uncertainty.

From the perspective of consumers, although short-term surpluses may be achieved in the importing market at the expense of buyers in the dumper's protected domestic

See P. Areeda \& D.F. Turner, "Predatory Pricing under Section 2 of the Sherman Act" (1975) 88 Harv. L. Rev. 697. Under the Areeda-Turner test, which has been accepted in U.S. law, prices which are below average variable cost are conclusively predatory, whereas prices between average variable cost and average total cost are permitted. The basic premise of Areeda and Turner is that it is economically rational for a firm to produce to a level where the marginal cost of the last unit produced equals the marginal revenue obtained in the market. Due to the practical difficulty in calculating marginal cost, courts have used average total cost, on the upper end, and average variable cost, on the lower end, as proxies.

Pricing below average total cost appears, admittedly, to be less accepted in Canada, where, as L. Hunter \& S. Hutton note, in the Predatory Pricing Enforcement Guidelines (Ottawa: Supply \& Services, 1992), the Canadian Bureau of Competition Policy has signalled that a lower threshold will be applied in Canada. Under what Hunter and Hutton describe as a "modified JoskowKlevorick approach" the Bureau states:

...a price set by a dominant firm above its average variable costs but below average total costs would be predatory unless the dominant firm could show that this was a loss-minimizing behaviour in the face of declining demand and/or excess industry capacity.

See L.A.W. Hunter \& S.M. Hutton, "Is the Price Right?: Comments on the Predatory Pricing Enforcement Guidelines and Price Discrimination Enforcement Guidelines of the Bureau of Competition Policy" (1993) 38 McGill L.J. 838 at 849. 
market, ${ }^{\text {st }}$ in the long run, they also stand to lose due to the lack of dependability of intermittent dumpers and the risk that viable alternatives to the dumper will be driven out of the market in the meantime by uncertainty. Indeed, in highly capital intensive industries, responding to the sudden surge in demand of the dumper's abandoned customers would be far from an instantaneous process. ${ }^{52}$

Applied to the context of the NAFTA, significant market segmentation, (i.e. the condition precedent for non-predatory dumping, including intermittent, non-predatory dumping), will continue to exist in the North American Free Trade Zone. Examples of such segmentation include the explicit maintenance of the privileged status granted to a select group of automobile and automobile parts manufacturers under the 1965 Agreement Concerning Automotive Products between the Government of Canada and the Government of the United States of America ${ }^{53}$ and monopolies that currently exist in fields such as telecommunications, ${ }^{54}$ and that can be obtained through intellectual property rights ${ }^{55}$ or under special provisions of the Competition $A c t^{56}$ will not be

See Warner, supra note 1 at 43.

32 What is less clear is the prevalence of intermittent dumping. Warner, ibid. at 57 cites a study conducted by Hutton and Trebilcock which examined thirty cases in which antidumping duties were imposed. Out of those cases, only four were identified where "...the possibility of an intermittent dumping concern was present...." The problem with such an ex post facto study is that antidumping duties are generally levied while dumping is occurring and before the harm caused to the importing consumers by abandonment occurs. It is submitted that it is always possible for the dumper to choose to no longer supply the importing market - the key lies in weighing the benefits of the dumper's lower prices against the perceived risk that the supply will be interrupted and that no alternative supply will be available at such time. The evaluation of what constitutes an "acceptable risk" will necessarily involve a policy choice of parties in the importing market. See S. Hutton \& M. Trebilcock, "An Empirical Study of the Application of Canadian Antidumping Laws: A Search for Normative Rationales" (1990) J. World Trade 123. See also infra for a list of relevant factors.

33 Can. T.S. 1966 No. 15 [hereinafter Auto Pact]. Pursuant to Article 1001 and Annex 1002.1 of the FTA and Appendix 300-A.1 of the NAFTA only the existing, primarily North American parties to the Auto Pact may qualify for that treaty's benefits, such as duty-free access to imports of parts from third countries (see Annex B(3) of the Auto Pact).

Under the NAFTA, a number of sectors of the economies of Canada, the United States and Mexico, including telecommunications, air transportation, areas of investment, etc., will be exempt from the application of the National Treatment and Most-Favoured-Nation standards. In the case of telecommunications, art. 1305 of the NAFTA binds parties to "ensure that the monopoly does not use its monopoly position to engage in anticompetitive conduct.... Such conduct may include crosssubsidization, predatory conduct...." It is submitted, however, that non-predatory, intermittent price discrimination on the part of such monopolists, which cannot be characterized as "anticompetitive" or "predatory", is beyond the scope of art. 1305 but should nonetheless be prohibited due to its unfair nature.

Although Chapter 17 of the NAFTA addresses intellectual property rights, there are still many instances in which holders of such rights will be able to use them as non-tariff barriers against competitors. For example, the issue of exhaustion of intellectual property rights remains unaddressed by the NAFTA. See C. Kent, "THE URUGUAY ROUND GATT TRIPS Agreement and Chapter 17 of the NAFTA: A New Era in International Patent Protection" (1994) 10 C.I.P.R. 711 at 720 .

Continued segregation of Canadian and U.S. markets with regard to patents should be contrasted against the dismantling of intellectual property barriers in the European Community. 
completely eliminated by the NAFTA. Furthermore, non-tariff barriers, such as subsidies and penalties which are unilaterally imposed by states under the guise of measures to "level the playing field" or "reprisals" will continue to be capable of being used in a protective manner until prohibited measures are adequately defined ${ }^{57}$ and effectively enforced. As previously discussed, although future discussions are envisaged, the NAFTA, as it stands, contains no progress on these matters. ${ }^{58}$ Another problem facing the NAFTA is that even in sectors where significant market segmentation has been eliminated, injured parties will remain at the mercy of the political will of their respective governments to enforce their rights under Chapter 20 dispute resolution, ${ }^{59}$ unless the matter under dispute involves antidumping or countervailing duties.

Thus, it is submitted that the North American market has not yet achieved the degree of free trade necessary to eliminate the potential for non-predatory, intermittent dumping and to give interested individual parties the ability to effectively remove sources of market segmentation. These are the challenges that must be met before no role remains for antidumping law in the North American market.

As will be shown in the next section of this article, it is likely more feasible to amend existing antidumping law to respond to North American free trade than to harmonize our existing competition (antitrust) laws given that Canadian competition law and U.S. antitrust law do not appear to address exactly the same policy objectives and given that neither body of competition (antitrust) law provides the appropriate response to intermittent, non-predatory dumping. It is to the scope of these bodies of law that this article will now turn.

S.C. 1986, c. 26. For example, inspired by the Economic Council of Canada's Interim Report on Competition Policy of 1969 (Ottawa: Queen's Printer, 1969), the Competition Act has recognized that tariff barriers create two problems: i) foreign tariff barriers limit the ability of Canadian firms to compete globally while ii) tariffs imposed by Canada on incoming goods favour generalization instead of specialization with the result of inefficient short production runs. Consequently, s. 86 of the Competition Act allows for "specialization agreements", which create exclusive markets as long as the Competition Tribunal is convinced that "...the agreement is likely to bring about gains in efficiency that will be greater than ... the effects of any prevention or lessening of competition that will result...."

For a discussion of the existing lack of definition of "subsidy" and the problems that result see R.J. Wonnacott, "Canadian Trade Policy for the 1990's" (1993) Policy Options 49 at 51:

The final important priority should be to cure the most serious error of omission in NAFTA (and, before it, the Canada-U.S. FTA): the failure to deal with the abuse of trade remedies. While Canada has been getting more relief from U.S. actions than it would be getting without the FTA's dispute settlement mechanism, there is still far too large an area of vulnerability. Reform should involve the negotiation of a subsidy code that will make transparent what is, and is not, beyond the reach of countervail.

39 See Kent, supra note 55 at notes 143-144. By contrast, pursuant to arts. $173 \mathrm{ff}$. of the Treaty Establishing the European Economic Community, 23 November 1957, 298 U.N.T.S. 11, individuals directly affected by European Community measures have standing to challenge the validity of such measures in the European Court of Justice. 


\section{COMPETITION LAW UNDER FREE TRADE: CAN IT FILL THE VOID?}

In buttressing their argument for the replacement of antidumping regulations with existing bodies of competition law, academics invariably point to the similarity of the goals of the free trade agreements and those of competition law. ${ }^{60}$ However, it is submitted that upon examination of the substance of relevant parts of Canada's competition law and the United States' antitrust law in light of the previously described reality of "free trade", three shortcomings become apparent:

1. Neither body of law, as it currently exists, provides an appropriate response to the possibility of non-predatory, intermittent dumping, which will be possible under the NAFTA;

2. Fundamental substantive differences exist between both bodies of law, reducing the likelihood of agreement on a uniform body of transnational competition law, or even adequate harmonization; and

3. Protectionist, and hence anti-free trade biases exist in both bodies of law, particularly where the behaviour under scrutiny involves "geographic price discrimination" or places the interest of the domestic market against foreign interests.

Consider the competition law remedies available to the victim of dumping. Under Canada's Competition Act, three principal bases of action are at the complainant's disposal:

i. To characterize the policy as "predatory pricing", contrary to subsections 50(1)(b or (c) of the Competition Act;

ii. To characterize the policy as an "abuse of dominant position", contrary to s. 79 of the Competition Act;

iii. To characterize the policy as non-primary line price discrimination, contrary to subsection 50(1)(a) of the Competition Act.

In the United States, two bases of action are primarily available: ${ }^{61}$

Section 1.1 of the Competition Act, supra note 56 reads in part that it is the purpose of the Act "...to maintain and encourage competition in order to promote the efficiency and adaptability of the Canadian economy, in Canada in order to expand opportunities for Canadian participation in world markets while at the same time recognizing the role of foreign competition in Canada...." [emphasis added].

While no equivalent purposive statement may be found in the United States, leading scholars and judges have characterized the role of antitrust law in a similar way. Bork, for example, sees the role of enhanced competition in the United States as "furthering productive and allocative efficiency" - ends synonymous with those sought by the NAFTA (Compare R. Bork, The Antitrust Paradox (New York: Basic Books, 1978) at 107-15 and the FTA, supra notes 3, 5-7).

6) Unfair methods of competition in or affecting commerce" may also be challenged outside the scope of traditional U.S. antitrust law under section 5(a)(1) of the Federal Trade Commission Act, 15 U.S.C.A. paras. 41-58. 
i. Characterization of the policy as "price discrimination", contrary to section 2(a) of the Clayton $A c t^{62}$ as amended by section 1 of the Robinson-Patman Act; ${ }^{63}$ or

ii. Characterization of the policy as "monopolization" or "attempted monopolization", contrary to section 2 of the Sherman Act. ${ }^{64}$

Subsections 50(1)(b) and (c) of the Competition Act, Canada's predatory pricing provisions, provide that:

50(1) Everyone engaged in a business who...

(b) engages in a policy of selling products in any area of Canada at prices lower than those exacted by him elsewhere in Canada, having the effect or tendency of substantially lessening competition or eliminating a competitor, or designed to have that effect, or

(c) engages in a policy of selling products at prices unreasonably low, having the effect or tendency of substantially lessening competition or eliminating a competitor, or designed to have such an effect,

is guilty of an indictable offence and is liable to imprisonment for two years. ${ }^{65}$

The Bureau of Competition Policy, in its Predatory Pricing Guidelines ${ }^{66}$ has interpreted the leading cases of $R$. v. Hoffman-LaRoche ${ }^{67}$ and $R$. v. Consumers Glass $^{68}$ to require two criteria to be satisfied before criminal conviction for predatory pricing may occur:

(1) the accused must have market power in the market in question; and

(2) the price of the predator must at a maximum be equal to its average total cost, although prices as low as average variable costs are justifiable if no other indices of predatory intent exist. ${ }^{69}$

This provision is subject to the same critique as the monopolization provision of the Sherman Act and subsections 50(1)(b) and (c) of Canada's Competition Act as predatory intent forms the basis of the offence. See infra, notes 76-79.

Price discrimination may also be challenged under the little used criminal provision of the first clause of $\mathrm{s}$. 3 of the $R P A$. Ch. 323, s. 2, 38 Stat. 730, (1914) (codified as amended at 15 U.S.C. s. 13 (1988).

Ch. 592, ss. 1-4, 49 Stat. 1526 (1936) (codified at 15 U.S.C. ss. 13-13b, 21 a (1988)) [hereinafter $R P A]$.

15 U.S.C. ss. 107 (1988).

Competition Act, supra note 56, ss. 50(1)(b) and (c).

Director of Investigation and Research, Competition Act, Predatory Pricing Guidelines (Ottawa: Supply and Services Canada, 1991) [hereinafter Predatory Pricing Guidelines].

(1980) 58 C.P.R. (2d) 1; 125 D.L.R. (3d) 607; 62 C.C.C. (2d) 118 (Ont. C.A.). (1981) 57 C.P.R. (2d) 1; 124 D.L.R. (3d) 274; 60 C.C.C. (2d) 481 (Ont. H.C.J.).

See discussion at supra note 49. As Hunter \& Hutton, supra note 49 at 844 point out, the Predatory Pricing Guidelines appear to contradict themselves in purporting to require market power as one of the two conditions precedent to predatory pricing and then stating that, even upon finding no market power exists: 
It is submitted that the rationale for requiring the accused to have market power in Canada in order to be convicted under section 50(1) of the Competition Act is inconsistent with the aim of protecting against non-predatory, intermittent price discrimination. In insisting upon the accused's being a "price-maker", Canadian competition law is linking predatory pricing with the accused's intention of eventually obtaining a monopoly and the likelihood of the latter occurring - both of which are irrelevant considerations for the non-predatory, intermittent dumper. Therefore, Canada's predatory pricing provision does not appear to respond to the case of the nonpredatory, intermittent dumper.

Section 2(a) of the Clayton Act, as amended by section 1 of the RPA (the United States' price discrimination provision), provides:

2(a) It shall be unlawful for any person engaged in commerce ... to discriminate in price between purchasers of different commodities of like grade and quality ... where such commodities are sold for use, consumption and resale within the United States and where the effect of such discrimination may be substantially to lessen competition.... ${ }^{70}$

One controversy which has surrounded interpretation of this provision, and is particularly relevant to the case of the non-predatory intermittent dumper, is whether predatory intent is a requisite element of the offence or whether proving harm to competitors is sufficient. The United States Supreme Court, in Utah Pie Co. v. Continental Banking Co., ${ }^{11}$ clearly adopted the latter approach. In Utah Pie, a regional producer of frozen pies holding 66.5 percent of the market share came under a situation of "geographic price discrimination", intense price competition from three national producers, within the Salt Lake City market. As a result, the firm saw its market share fall to 45.3 percent despite an increase in sales. Even though the plaintiff was still profitable and despite the consumer benefits associated with the regional producer's loss of its dominant position and lower prices, the Supreme Court held that the behaviour of the national producer's behaviour "may lessen competition within the meaning of section two when it produces a 'drastically declining price structure'."72

The significance of the Utah Pie decision is twofold. In the first place, the decision represents a basis on which a successful claim against non-predatory intermittent dumping may be made by means of existing antitrust law. A previously discussed, the unfairness in such dumping lies not in the dumper's intent to lessen competition, but in the effects of such behaviour: intense price competition in the importing market without equal access to the dumper's market and market-distorting uncertainty. Utah Pie, by adopting an effects-on-competitors test, places the non-predatory, intermittent dumper within the scope of the Clayton Act. However, by focusing solely on the existence of discrimination and its effects on competitors, the decision opens up a basis 
of claim for all forms of dumping, including beneficial persistent dumping, as long as a "drastically declining price structure" can be established. The anti-competitive (and anti-free trade) consequences of this line of reasoning are clear. In the words of Charles F. Rule, a previous Assistant Attorney General in charge of antitrust law in the United States:

At a time when inefficient domestic firms are seeking any and all forms of protection from their more efficient foreign rivals, such open invitations to attack vigorous competition will likely result in a significant increase in spurious predatory pricing suits. ${ }^{73}$

Canada's price discrimination provision, subsection 50(1)(a) of the Competition Act reads in part:

50(1) Every one engaged in a business who...

(a) is a party or privy to, or assists in, any sale that discriminates to his knowledge ... against competitors of a purchaser of articles from him in that any discount, rebate, allowance, price concession or other advantage is granted to the purchaser over and above any discount, rebate, allowance, price concession or other advantage that, at the time the articles are sold to the purchaser, is available to the competitors in respect of sale of articles of like quality and quantity,

is guilty of an indictable offence and liable to imprisonment for a term not exceeding two years.

It is important to note that there is no specific action for primary line price discrimination ${ }^{74}$ under Canada's Competition Act. As well, although it has yet to be jurisprudentially interpreted, this provision shows signs of strength and weakness as a tool against dumping. On one hand, by merely requiring demonstration of discrimination against a competitor as opposed to predatory intent and injury to competition, ${ }^{75}$ subsection $50(1)$ (a) shows signs of the flexibility required to address intermittent dumping. On the other hand, as previously noted, the scope of the rule is extremely limited as it only applies with regard to cases of discrimination against competing purchasers. Indeed, very few purchasers of dumped products would likely be found to geographically "compete" with purchasers in the dumper's domestic market. Furthermore, in order to be liable under subsection 50(1)(a), a practice of discrimination must be found. ${ }^{76}$ It is unclear to date whether the activity of an

M.L. Denger et al., "60 Minutes with Charles F. Rule" (1989) 58 Antitrust L.J. 377 at 380.

74 Hunter \& Hutton, supra note 49 at 865 , describe "primary line price discrimination" as follows: Paragraph 50(1)(a) only prohibits price discrimination between businesses which the seller knows to be competitors of one another in their downstream markets. Since consumers, charities and non-market government institutions do not have any downstream markets, price discrimination against these groups is not constrained by the Act. (Toronto: Butterworths, 1992) at 152, it is far less onerous to show injury to a competitor than to show injury to competition. 
intermittent, non-predatory dumper, whose activity is temporary and uncertain by definition, would qualify as a 'practice'.

Alternatively, the victim of dumping may base an action under the abuse of dominant position and monopolization provisions of Canada and the United States respectively. Section 78 of the Canada's Competition Act provides a non-exhaustive list of "anticompetitive" acts, which include:

i. selling articles at a lower price than the acquisition cost for the purpose of disciplining or eliminating a competitor. ${ }^{77}$

Section 79 authorizes the Competition Tribunal to issue an order of prohibition if it finds that:

(c) the practice has had, is having or is likely to have the effect of preventing or lessening competition substantially in the market. ${ }^{78}$

The Canadian Competition Tribunal has interpreted these provisions in the case of Canada (Director of Investigation and Research) v. The Nutrasweet Company, ${ }^{79}$ which is another decision of particular relevance to this article because of the similarity of the behaviour under scrutiny and dumping. In Nutrasweet, a complaint was made against the use of Nutrasweet's U.S. patent as leverage to conclude exclusive supply contracts with Canadian firms and against the use of the firm's monopoly position in the U.S. to subsidize its lower Canadian price. In concluding that Nutrasweet's acts were anticompetitive, the Competition Tribunal declared that "the use of a monopoly position (created by the United States patent) to obtain a competitive advantage for a dominant firm in another market is an anti-competitive act"..$^{80}$ Note that similar to Canada's predatory pricing provision, the anti-competitiveness of Nutrasweet's actions was linked to the intention of an already dominant firm to gain a stranglehold on the Canadian market. Thus, the complainant against non-predatory dumping would likewise be out of luck under Canada's abuse of dominance provision.

Similarly, the complainant would not succeed in an action under section 2 of the Sherman Act, which reads in part:

2. every person who shall monopolize ... any part of the trade or commerce among the several states, or with foreign nations, shall be deemed guilty of a felony.....

Competition Act, supra note 56, s. 78(i).

Competition Act, ibid. s. 79(1)(c).

C.T. October 5, 1990 (Decision of the Competition Tribunal) [hereinafter Nutrasweet].

Ibid. at 80 .

Sherman Act, supra note 64, s. 2. 
Feltham summarizes the two substantive conditions that leading jurisprudence, such as Catlin v. Washington Energy Company ${ }^{82}$ has developed for conviction under section 2:

1. Possession of monopoly power in a relevant market, and

2. wilful acquisition or maintenance of that power.

Two problems exist under such a claim, negating the possibility of remedial action against non-predatory intermittent dumpers:

1. The non-predatory, intermittent dumper may not have monopoly power in the U.S. market to begin with, and

2. The act of intermittent dumping is in no way per se demonstrative of an intention to acquire or maintain monopoly power in the relevant U.S. market.

In light of the above discussion, it is clear that if competition (antitrust) laws are to fairly and effectively govern transnational as well as domestic business in the Canadian and U.S. markets, significant modifications to each body of law will be necessary. In the United States, non-predatory, intermittent dumping could be regulated by legislatively recognizing the Utah Pie doctrine, but limiting its scope to instances of intermittent price discrimination instead of mere "geographic discrimination". In Canada, existing price discrimination law could be modified to encompass intermittent, primary line discrimination.

The above changes, however, would only be the beginning. When compared with section 2(a) of the RPA, Canada's price discrimination law, is also illustrative of the fundamental differences between existing Canadian and U.S. competition/antitrust laws on a broader level. Canada's Director of Investigation and Research has stated that activity akin to sporadic dumping, so-called "one-shot" discounts, would not violate the Canadian price discrimination provision. ${ }^{83}$ On the other hand, s. 2(a) of the RPA exempts price discrimination from the scope of the section if the narrow criterion of "showing that his lower price ... was made in good faith to meet an equally low price of a competitor" can be met. In addition, while section 2(a) of the RPA requires the seller to legitimate volume-based price differentials by cost savings, no such cost justifications are necessary under Canadian law. ${ }^{84}$ Fundamental differences also exist at the level of remedies available to private parties: under U.S. law, treble damages may be claimed by private parties under section 4 of the Clayton Act against perpetrators of antitrust violations, versus mere single damages under the Competition Act. ${ }^{85}$

n. D.H.W. Henry, Q.C., "Unfair Distribution and Pricing Practices", Trade Competition and the Law, Special Lectures of the Law Society of Upper Canada (Toronto: Richard de Boo, 1963) at 43-44, cited in Roberts on Competition/Antitrust: Canada and the United States, supra note 75 at 160. 
These differences are not insignificant. While formally satisfying the national treatment standard, it could be argued that the abovementioned features of U.S. price discrimination law tend to favour producers which have achieved greater cost savings through economies of scale and to which the prospect of facing a treble damages suit would probably appear less prohibitive - in other words established (which would be, for the most part, domestic) firms. ${ }^{86}$

In light of the degree of difference between applicable Canadian and U.S. competition (antitrust) law, and considering the entrenchment of each body of law particularly U.S. antitrust law - in the fabric of each society, one must ask whether it would not make more practical sense to maintain antidumping law in Canada and the United States until our markets are sufficiently integrated to eliminate non-predatory, intermittent dumping. If antidumping laws were to be maintained, the scope of activity prohibited by these laws would need to be reduced to recognize that only one form of non-predatory price discrimination, intermittent dumping, warrants prohibition in the market created by the NAFTA. This would mean that harmonized tests would have to be developed to distinguish intermittent from sporadic or permanent dumping. Factors relevant to the scope of punishable intermittent dumping would include, inter alia: the short-term consumer benefits of the lower prices of the dumper, the length of time of the undertaking to supply the importing market by the scrutinized firm, prior activity of the dumper, and the ease with which competitors may enter the market in the event that the dumping ceases. Obviously, the capital intensity of the industry sector under scrutiny would be relevant to the last factor.

One final point should be made that is related to the current state of Canadian competition law. Similar to the Utah Pie decision in the United States, the Competition $A c t$, in places, may be subject to allegations of incompatibility with the NAFTA and the $F T A$ 's principles of national treatment and promoting "vigorous transborder price competition". Two examples of such vulnerability are the provisions for specialization and export agreements. Under section 86 of the Competition Act, a party may apply to the Competition Tribunal for exemption from sections 45 and 77 , the cartel and exclusive dealing provisions, if:

(a) the implementation of the agreement is likely to bring about gains in efficiency that will be greater than, and will offset, the effects of any prevention or lessening of competition that will result....87

In considering what constitutes a gain in efficiency, section $86(2)(b)$ of the Competition Act authorizes the Competition Tribunal to examine whether there has been "a significant substitution of domestic articles or services for imported articles or services." ${ }^{88}$ Similarly, section $45(5)$ of the Competition Act immunizes cartels from 
prosecution as long as they relate "only to the export of products from Canada." ${ }^{89}$ In other words, Canada has declared its willingness to overlook the net anti-competitive detriment to the North American and global markets that such agreements may have as long as the calculus of net benefit within Canadian boundaries is positive.

\section{CONCLUSION}

One cannot dispute that the concerns raised regarding the compatibility of Canadian and U.S. antidumping provisions with the spirit of the NAFTA and the FTA are, to a large degree, valid. These regulations, by punishing all forms of non-predatory price discrimination, deny these agreements' stated goal of enhancing North American competitiveness and may be challenged as contrary to the principle of national treatment. However, it is the opinion of this author that, given the reality achieved under the NAFTA, the North American market is not quite ready for the complete elimination of antidumping law in favour of an overarching body of competition (antitrust) law. Rather, these arguments should serve as the basis for reducing the scope of existing antidumping law to predatory and intermittent dumping.

Neither body of competition (antitrust) law provides a satisfactory remedy to the phenomenon of dumping that will result in the so-called environment of "free trade". Furthermore, if and when our markets become sufficiently integrated to justify the replacement of antidumping law with a competition/antitrust regulation mechanism, some significant philosophical differences in our countries' approaches to competition/antitrust enforcement will have to be overcome. Finally, the very premise that proponents of replacement of antidumping provision with competition law base their argument on - that existing competition law is in accordance with the spirit of the NAFTA and the FTA - is debatable in places. It has been shown that U.S. cases such as Utah Pie and Canadian provisions of the Competition Act for export and specialization agreements appear to contradict the guiding principles of the NAFTA and the FTA. Thus when members of the Working Group on Trade and Competition convene, they would be well advised that North America should learn to crawl before it learns to run on matters of integrated economic regulation. 